\title{
尿管腫瘍の臨床的研究
}

\begin{tabular}{|c|c|c|c|c|c|}
\hline \multirow{5}{*}{$\begin{array}{c}\text { 東京慈恵会医科大学泌尿器科学教室 } \\
\text { (主任: 町田豊平教授) }\end{array}$} & & 井 & & 由 & \\
\hline & 増 & 田 & 富 & \pm & \\
\hline & 菱 & 沼 & & 秀 & \\
\hline & 仁 & 々 & 木 & 忠 & \\
\hline & 町 & 田 & & 豊 & \\
\hline 帝京大学医学部第 2 病理学教室 & & 坂 & 井 & & \\
\hline
\end{tabular}

\section{A CLINICAL STUDY ON URETERAL TUMOR}

\author{
Yoshikazu Arai, Fujio Masuda, Hideo Hishinuma, Tadamasa Sasaki and \\ Toyohei Machida \\ Department of Urology, The Jikei University School of Medicine \\ (Director: Prof. T. Machida) \\ Mamoru Kozakai \\ Department of Pathology, Teikyo University School of Medicine
}

The present paper is concerned with our review on the clinical results of a total of 21 patients with ureteral tumor, who were seen at Jikei University Hospital in the 17 years' period from 1960 to 1976.

The average age of the 21 patients was 63 years. The ratio of men to women was 4.3 to 1 . The left side was involved in 12 cases and the right in 8 cases. Only one out of the 21 patients had bilateral ureteral tumors which were diagnosed 4 years apart.

The lower third of the ureter was involved in 12 cases $(55 \%)$, the middle third in 2 cases $(9 \%)$ and the upper third in 7 cases $(32 \%)$. The entire ureteral length was affected in one case.

The most frequent initial symptom was gross hematuria in 18 cases $(82 \%)$, followed by pain in 4 cases $(18 \%)$.

The common symptoms were gross hematuria in 18 cases (82\%), pain in 9 cases $(41 \%)$ and palpable mass in 3 cases (14\%). Nonurologic symptoms such as general malaise were seen in 6 cases $(27 \%)$.

Laboratory tests revealed anemia in 4 cases (18\%), accelerated ESR in 3 cases $(14 \%)$, increased $\alpha_{2}$-globulin in 4 cases $(27 \%)$ and urinary infection in 2 cases $(9 \%)$.

Urinary cytologies carried out in 12 cases were positive for tumor cell in 2 cases $(17 \%)$.

Blood was seen at the ureteral orifice in 2 of 22 cases and in further 4 cases tumor was visualized protruding from the ureteral orifice. In these 6 cases $(27 \%)$, the lesions were in the lower third of the ureter. Hematuria was noted from the affected ureter in 3 cases (14\%), whose lesions were in the upper third of the ureter.

Ureteral catheterization was performed in 15 cases. Ureteral catheterization was difficult or impossible in 12 cases $(80 \%)$, and in the remaining 3 cases, the ureteral catheter was passed to the kidney without meeting any obstruction. The Chevassu-Mock's sign-increased ureteral bleeding following manipulation at the site of the tumor-was noted in 6 cases (40\%), and Marion's sign-drainage of clear or clearing urine after passage of the ureteral catheter beyond the tumor-was noted in 2 cases $(13 \%)$.

Excretory urography was performed in all the cases and retrograde urography in 14 cases. Urography showed ureteral filling defect in 14 cases $(64 \%)$, ureteral obstruction in 2 cases $(9 \%)$, hydronephrosis with or without hydroureter in 15 cases $(68 \%)$ and nonvisualization in 6 cases $(27 \%)$. 
$7(33 \%)$ out of 21 patients had pelvis, bladder and/or opposite ureteral tumor either previously, concurrently, or subsequently.

$18(82 \%)$ out of 22 cases underwent total nephroureterectomy with excision of a periureteral cuff of bladder. 3 cases $(14 \%)$ underwent partial ureterectomy and simple nephrectomy was performed in one case.

The 5-year survival rate in 21 patients was $40 \%$, showing a close correlation of prognosis with histological grade and stage. 5 out of 6 patients, in whom the kidney was not visualized on the excretory urogram died within 5 years.

\section{緒言}

尿管腫瘍は他の尿路上皮腫瘍である腎孟腫瘍, 膀胖腫 瑝に比べて，予後は不良であるといわれる。しかし本症 は発生頻度が少なく, したがつて 1 機関で多くの症例を 対象とした検討は少ない.われわれは慈恵医大附属病院 そ颃いて，1960年より1976年までの17年間に尿管腫瘍を 21名, 22例 ( 1 例は両側尿管に非同時性に発生) 経験し たので，その臨床的観察を行ない，あわせて文献的考察 を加えて報告する。

\section{臨床的観察}

\section{1. 発生頻度}

17 年間の 外来新患々者数は 45,065 名, 入院患者数は 6,421名で，そのらち尿管腫演と診断されたものは21名 であり，外来患者および入院患者に対する比率はそれぞ れ0.047\%および0.33\%であつた。 またこの間の腎孟腫 瘍は19名でほぼ同数であつた。

2. 年齢, 性別, 患側

年齢は21名すべて 40 歳以上で, 最年長は79歳, 平均年 秢は63歳であつた。

性別は男子17名, 女子 4 名と, 男子は女子の 4.3 倍で あつた（表 1).

表 1 年令・性別

\begin{tabular}{c|c|c|c|c|c}
\hline & $40 \sim 49$ & $50 \sim 59$ & $60 \sim 69$ & $70 \sim 79$ & 計 \\
\hline$\hat{8}$ & 2 & 6 & 3 & 6 & 17 \\
\hline$ㅇ$ & 0 & 0 & 3 & 1 & 4 \\
\hline 計 & 2 & 6 & 6 & 7 & 21 \\
\hline
\end{tabular}

患側は左13例，右 9 例と左尿管に多くみられたが，こ のらち 1 例は最初左側に，4 年の間隔を括いて右側に発 生した両側性のものである.

3. 部位

発生部位は尿管の上部 $1 / 3$ 7 例 $(32 \%)$, 中部 $1 / 3 か ゙$ 2 例 ( $9 \%$ ), 下部 $1 / 3$ が12例 $(55 \%)$ と下部 $1 / 3$ に最も多 く認められた。さらに 1 例は腫瑒が全尿管に多発してい
表 2 部位・患側

\begin{tabular}{c|c|c|c}
\hline & 左 & 右 & 計 \\
\hline 下部 $1 / 3$ & 6 & 6 & $12(55 \%)$ \\
\hline 上部 $1 / 3$ & 5 & 2 & $7(32 \%)$ \\
\hline 中部 $1 / 3$ & 2 & 0 & $2(9 \%)$ \\
\hline 全 域 & 0 & 1 & $1(5 \%)$ \\
\hline 計 & 13 & 9 & 22 \\
\hline
\end{tabular}

表 3 臨床症状（22例）

\begin{tabular}{c|c}
\hline 症 状 & 例 数 \\
\hline 血 尿 & $21(95 \%)$ \\
\hline 肉眼的血尿 & 18 \\
\hline 顕微鏡的血尿 & 3 \\
\hline 疼 痛 & $9(41 \%)$ \\
\hline 腫 瘤 & $3(14 \%)$ \\
\hline 膀脱刺戟症状 & $3(14 \%)$ \\
\hline 全身倦点感 & $4(18 \%)$ \\
\hline 胃腸症状 & $3(14 \%)$ \\
\hline 体重減少 & $3(14 \%)$ \\
\hline 発 熱 & 1 \\
\hline
\end{tabular}

た注か，下部 $1 / 3$ の尿管に発生した 12 例中 2 例は，いず れ子腫瘍が 2 力所浔められた（表 2 ).

また膀胱腫瘍の治療後に発生した 3 例は，すべて下部 1/3に生じている.

4. 初発症状

肉眼的血尿が 22 例中 18 例， $82 \%$ と圧倒的に多く認めら れた。のこりの 4 例は疼痛を初発症状としたが，いずれ る肉眼的血尿は伴なつて扣らず，1例に発熱がみられ た。

\section{5. 臨床症状}

初発症状を含めた臨床症状についてみると, 表 3 のご とくである. 肉眼的血尿は 22 例中 18 例と最も多くにみら れたが，1 例は顕微鏡的血尿も認められなかつた. 
疼痛は 9 例， $41 \%$ そられたが，1例は疝痛様発作で あつた． 9 例中, この 1 例を含めた 4 例は肉眼的血尿は 認めて抢らず，尿管腫瘍における疼痛は，腫瘍による尿 流障害に起因するものが多いと思われる．

腫瘤は 3 例，14\%にみられたのみである。このらち 2 例は，腫瘍により高度の水腎症になつた腎を触知したも のであり，1 例は尿管腫瘍が周囲に浸潤し，腫瘤を形成 したものであつた。

しかしこれら三大症状のそろつたものは，22例中 1 例 もなかつた。

尿路外症状は 6 例，27\%に認められたが，全身倦急感 が 4 例と最も多く, 体重減少, 胃腸症状が各 3 例にみら れた。

\section{6. 臨床検査成績}

(1) 血液検查

赤血球数 $350 \times 10^{4}, \mathrm{Hb} 11.0 \mathrm{~g} / \mathrm{dl}$ 以下の貧血は 22 例中 4 例, $18 \%$ に認められた.

(2) 赤沈

1 時間値 $30 \mathrm{~mm}$ 以上の六進 は 3 例， $14 \%$ みられた が，らち 2 例は貧血を伴なつていた。，一方 6 例は 1 時間 值 $10 \mathrm{~mm}$ 以下であつた.

（3）血液化学検查

血清蛋白像は15例について検討したが， $\alpha_{2}$-globulin の 上昇をみたが 4 例， $27 \%$ であつた.

また肝機能検査では GOT, GPT の上昇を示したのが 3 例みられたが，5ち 1 例は10年前より肝硬変で加療を らけていたもので, LDH, ビリルビン值の上昇も伴なつ ていた。

\section{（4）尿路感染}

2 例に尿路感染がみられた。1 例は腎盂腎炎による疼 痛と発熱を主訴として来院し, 精査の結果, 尿管腫瘍の 発見されたものであるが, 他の 1 例は尿閉でカテーテル 留置の施行された例であつた。

（5） 尿中細胞診

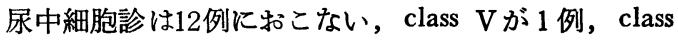
IVが 1 例と 2 例に陽性であつた。 のこりの10例は class III が 4 例, class II およびI が 6 例である。 また陽性例 の 2 例の摘出標本の組織学的悪性度は, grade II および grade IVであつた。

7. 膀胱鏡検查㧊よび尿管カテーテル法

(1) 膀脂鏡検查

22例の膀羘鏡検査で，腫瘍が尿管口より突出している のを認めたものは 4 例, 尿管口部の膨隆をみたものが 1
表 4 膀胱鏡検査（22例）

\begin{tabular}{l|c|c}
\multicolumn{1}{c|}{ 所 見 } & \multicolumn{2}{|c}{ 例 数 } \\
\cline { 1 - 2 } 尿管口よりの腫湯の突出 & 4 & \multirow{2}{*}{$5(23 \%)$} \\
\cline { 1 - 2 } 尿管口の膨隆 & 1 & \\
\cline { 1 - 2 } 尿管ロよりの血尿 & 3 & \multirow{2}{*}{$5(23 \%)$} \\
\cline { 1 - 2 } 尿管ロよりの出血 & 2 & \\
\hline
\end{tabular}

例，さらに尿管口の收縮とは無関係に尿管口より出血の みられたものが 2 例であつたが，これら 6 例 (27\%) は すべて下部1/3の尿管に腫場が発生したものである。 た尿管口より血尿の排出を認めたものは 3 例で，いずれ も上部 $1 / 3$ の尿管腫瘍であつた（表 4 ).

また併発した膀腃腫瘍を認めたものは 1 例であつた。

（2） 尿管カテーテル法

15例に尿管カテーテル法を行なつた。カテーテルが腫 瘍部でつか光，挿入不能であつたものは 8 例，抵抗はあ るものの插入可能なものは 4 例，なんら通過障害のなか つたものは 3 例であつた.

カテーテルが腫瘍と接触したため血尿の誘発や増強を みたもの (Chevassu-Mock's sign) 6 例，カテーテルが 腫瘍部を通過すると血尿が澄清色となつたもの(Marion s'sign) は2 例であつたが, 腫瘍直下でカテーテルがとぐ ろを巻く現象 (Bergman s'sign)をみたものは1例もな かつた（表 5).

表 5 尿管カテーテル法（15例）

\begin{tabular}{c|c|c}
\hline \multicolumn{1}{c|}{ 所 見 } & \multicolumn{2}{|c}{ 例 数 } \\
\cline { 1 - 2 } カテーテル㪙入 & & \\
\hline 不 能 & 8 & \multirow{2}{*}{$12(80 \%)$} \\
\hline 抵 抗 & 4 & \\
\hline 容 易 & 3 & \\
\hline 尿の変化 & & \\
\cline { 1 - 2 } Chevassu-Mock's sign & 6 & \multirow{2}{*}{$8(53 \%)$} \\
\cline { 1 - 2 } Marion's sign & 2 & \\
\hline
\end{tabular}

すなわち15例中14例，93\%は尿管カテーテル法により 何らかの所見がみられており, カテーテルの通過障害も なく，尿の変化も生じなかつたものは 1 例のみであつ た。

8. X線学的検查

（1）腎尿管膀脱部単純撮影

腎部に軟部腫瘤を認めたものは 2 例で，いずれも巨大 
な水腎症を呈したものである，尿管結石は 1 例にみられ たが，腫場とは反対側であり，結石を合併した尿管腫瘍 はなかつた。

（2） 尿路造影

排泄性腎孟造影は22例全例儿行ない，逆行性腎孟造影 は14例に施行した. 22例中14例は腫瘍による尿管の充満 欠損を，2 例は通過障害像が認められた。またこれら16 例 $(73 \%)$ 中 15 例は腫瘍存在部より上部の尿管や腎盂の 拡張がみられ，さらに 3 例は腫瘍直下の尿管の拡大も認 められたが, stage A の1例のみは尿路の拡張をみなか つた.

6 例は無造影腎であつたが，このうち腫瘍の浸潤が筋 層以上に達していたものは 5 例であつた（表 6 ）.

表 6 尿路造影像（22例）

\begin{tabular}{l|c}
\multicolumn{1}{c|}{ 所 見 } & 例 数 \\
\hline 水腎症および水尿管症 & $15(68 \%)$ \\
\hline 尿管允満欠損 & $14(64 \%)$ \\
\hline 無造影腎 & $6(27 \%)$ \\
\hline 腫瘍直下の尿管の拡張 & 3 \\
\hline 尿管通過障害 & 2 \\
\hline 正 常 & 1 \\
\hline
\end{tabular}

（3）血管造影

大動脈造影および腎動脈造影は 6 例に施行した。腫瘍 血管像の明らかに認められたものは上部 $1 / 3$ 発生した 1 例のみであつたが，のこりの 5 例わ，腎腫瘍との鑑別 などに有用であつた。

9. 併発尿路上皮腫瘍

21名のらち腎盂，膀胱または反対側尿管に移行上皮性 腫瘍の発生をみたものは 7 例，33\%であつた。 7 例中 2 例は腎孟に，1 例は腎孟および膀胱に，3 例は膀胱に， 1 例は膀胱执よび反対側尿管に生じている. 腎孟に腫瘍 のみられた 3 例はすべて同側であつた。

つぎに発生の時期よりみると，尿管腫瘍の診断と同時 に認められたものは 7 例中 3 例である。また 1 例は術後 4 力月目に膀胱腫瘍が発見されて括り，1例は術後11力 月目に膀胱腫瘍を,さらに 3 年 1 力月後に反対側の尿管 腫瘍を認めている。一方 2 例は, 膀脱腫瘍の治療後 7 年 5 カ月抢よび 8 年 2 カ月後に 尿管腫瘍が発見されてい る。

10. 治療

22例全例に手術を施行した.18例は尿管口周辺の膀胱
表 7 手術々式（22例）

\begin{tabular}{l|l}
\hline 術 式 & 例 数 \\
\hline 腎尿管全摘出術兼膀胱壁切除 & $18(82 \%)$ \\
\hline 尿管部分切除術 & 3 \\
\hline 腎 摘 除 術 & 1 \\
\hline
\end{tabular}

壁の一部を含めて，腎尿管全摘出術を行なつたが，1 例 は腫瘍の浸潤が強く腎摘出術のみに終つた。.のこりの 3 例は尿管部分切除術を行なつたが，このうち 1 例は残腎 飞発生したものであり，2 例は low grade の症例であつ た（表 7 ).

放射線療法を行なつたるのは 7 例で, 主として術後腫 瘍部に 3,000 ５000rads 照射している.

化学療法は10例に施行した.初期の 5 例はmitomycin C の投与を行なつたが，最近の 5 例は MFC 療法すすなわ ち mitomycin C $2 \mathrm{mg}$, 5-fluorouracil 250mg, cytosine arabinoside $20 \mathrm{mg}$ を術後より週 2 回, 合計10回行なつて いる。

11. 病理学的所見

22例について，次のような基準で grade と stage を 分類した。

組織学的 grade はIからIVまでに分けたが, grade I は正常粘膜の乳頭状増殖で，各細胞間の異型や mitosis のないもの, grade II は各細胞間に軽度の異型があり, 時に giant cell あみられるが, mitosis はあつても軽度 で浸潤性発育も軽く, 全体的に軽度の 变化を呈するも の, grade III grade II にみられた変化の強いもので, 時に扁平上皮化のあるもの，grade IVは未分化癌とし た。

stage はAからDに分類したが， stage A は粘膜下層 まで， stage B は筋層まで浸潤のみられるもの， stage C は尿管外膜まで执よんでいるもの， stage D は尿管周 囲組織まで浸潤し，ときに局所または遠隔転移のみられ るものとした。

22例を上述の組織学的 grade でみると, grade I は 1 例, grade II は13例, grade III 4 例, grade IVは 4 例 であつた。また stage をみると stage A は11例, stage B は 5 例, stage $C$ は 3 例, stage $D$ は 3 例であつた。

\section{2. 転㷌}

尿管腫瘍21名の転帰 をみると因 1 のごとくである． な和生存率は，1963年 international symposium on end result of cancer therapy で採用された計算法に準じて， 実測生存率をるとめた。 21 名の 1 年生存率は $59 \%, 3$ 年 
図 1 生存率(21名)

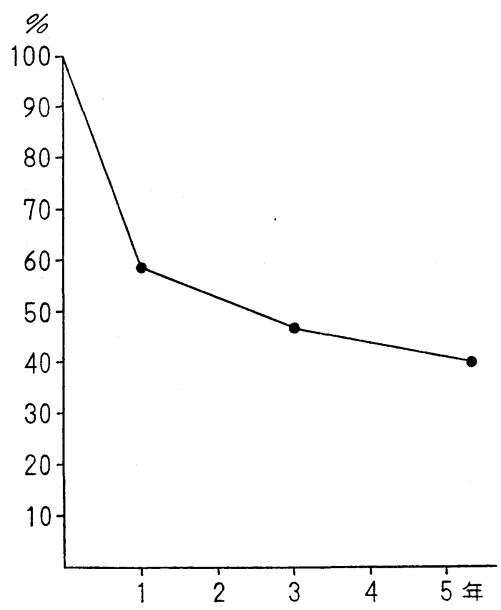

生存率は $47 \% ， 5$ 年生存率は $40 \%$ であつた。

つぎに stage および grade と生存率との関係をみる と, stage A 10例の 5 年生存率は63\%であるのに対し, stage B 拉よびCの 8 例では $29 \%$ であり, stage D の 3 例では生存例はなかつた。 一方 low grade (grade I およびII） 13例の 5 年生存率 は63\%であるのに対し， high grade (grade III 拈よびIV) 8 例中 7 例は 5 年以内 に死亡しているまた腎が無造影であつた 6 例中， 5 年 生存例は 1 例のみであつた。

\section{総括ならびに考察}

尿管腫瘍は比較的稀な疾患であり，その発生頻度は腎 盂腫瘍とほぼ同じで, 膀胱腫崵の1/36〜1/51 といわれて (いる ${ }^{12) 3)}$ ．自験例でも尿管腫瘍は腎盂腫瘍の1.1倍で, ほぼ同数であつた。

性別では腎酉腫瘍と同様に男子に多くみられ，その性 比は2:1〜5.5:1(2)34)5) といわれているが，自験例で は男子は女子の4.3倍であつた。

患側は自験例のように左に多い(2) とも，また逆に右側 に多(4)5) ともいわれるが，これらの報告をあわせてみ ると左右差はないようである。

年㱓は60歳〜 70 歳台に最も多くみられたのは従来の報 告3) 4) 5) と同様である.

発生部位は下部 $1 / 3$ の尿管に最も多く,ついで上部 $1 / 3$, 中部1/3の順であつた，従来の 報告も同様で，尿管腫場 の46〜 73\%は下部1/3に発生している(5)6)。 また膀胱腫 瘍治療後に発見された 3 例はいずれも下部 $1 / 3$ 発生し て怙りこのことは腫瘍細胞が，逆流により下部尿管に 播種性転移したことを示すのかもしれない.さらに腫瘍
の多発した例が 3 例あつたことは，本症の治療上留意す べきことである.

初発症状としては，肉眼的血尿が $82 \%$ と圧倒的に多か つたことは腎㙉腫瘍" と同様である。

臨床症状としても最も多いのは血尿で, 74〜92\% \% にみられている. 自験例でも22例中 21 例，95\%に認め ており，血尿はまず必発の症状といつてよい，疼痛は 2 番目に多い症状で 9 例， $41 \%$ にみられた。このらち 4 例 は肉眼的血尿を伴なつて拈らず，尿管腫瘍の疼痛は腫瘍 による尿路の通過障害に起因するるのが多いと考兄られ る.腫瘤が認められたものは腎細胞癌") や腎孟腫瘍" $に$ 比べて少なく，3例，14\%であつた。一般に腫瘤触知は 主症状のなかで最も少なく，7 8.5\% ${ }^{338)}$ といわれてい るが, 半数浔めたとの報告”もある.

尿路外症状は腎細胞癌 ${ }^{10)}$ 之同様に多くみられ，6例， 27\%に認められた。うち1例は腎血腎炎による発熱を主 訴として来院したが, 本症は尿路の閉塞をおこすと, 感 染が合併し易くなる。

尿管腫瘍の尿中細胞診の陽性率について, Batata ${ }^{2)}$ は 29\%, Saranachi ${ }^{11)}$ は70\%といっている。また徳中 ${ }^{12)}$ は 上部尿路上皮腫瘍の尿沈渣の Papanicolaou 検査で， 7 例の high grade の腫場中 6 例は陽性であつたが, low grade の 2 例では陰性であつたという．自験例では12例 中 2 例，17\%の陽性率であつたが, grade よりみると， high grade では 2 例中 1 例, low grade では10例中 1 例 が陽性であつた。

膀胱鏡検査では 22 例中 9 例， $41 \%$ に病的所見が みら れた。特に下部 $1 / 3$ に発生した 12 例中 6 例は尿管口より の腫瘍の突出や出血が認められ，尿管腫瘍と診断され た. Williams ${ }^{1)}$ は34例中 5 例に尿管口よりの出血を, 6 例に腫瘍の突出をみているが，この11例はすべて下部 1/3の尿管腫煬であつたという．また Bloom ${ }^{3)}$ は102例 の観察で，尿管口よりの出血は $21 \%$, 腫煌の突出は $6 \%$ にみられ，さらに膀胱腫瘍の併発を $8 \%$ に認めたとい 5 .

いずれにせよ血尿がみられた時は，直ちに膀胱鏡検査 を行なつて出血部確認の一助としなければならない，尿 管口の収縮に伴なつて間歇的に血尿が排泄される時は， 上部尿路からの出血であることは判断されるが，積極的 に尿管腫瘍といらことは出来ない，乙かし尿管口の収縮 とは関係なく，持続的に出血する場合は尿管腫汮の確率 は相当高く，さらに尿管口より腫瘍が突出している時は 本症の診断が決定的である. 
尿管カテーテル法で尿管腫瘍を疑わせる所見は, カテ 一テルの通過障害とカテーテルにより若起される血尿な どであり，自験例では15例中14例，93\%に認められた。 Bloom $^{3)}$ む約半数は尿管カテーテルがつかえ挿入不能で あつたといい，Batata ${ }^{2)}$ む3\%に閉塞がみられたといつ ている。

堅尿管膀胼部単純撮影では, 腫大した腎影や結石が認 められることがある．自験例では水腎症による軟部腫瘤 を 2 例にみたが，結石を合併したものは 1 例もなかつ た。

尿路造影でみられる主要な所見は，腫瘍による尿管の 充満欠損や通過障害像, 腫瘍存在部より上部の尿管拉よ び腎盂の㧪張であり，自験例では22例中16例，73\%に認 められた. Williams ${ }^{1)}$ は排泄性腎孟造影で30例中28例， 93\%に病変像がみられた といい，Batata ${ }^{2)}$ は排泄性腎 孟造影で尿管の充満欠損は19\%，水腎症は34\%に認めら れ，さらに逆行性腎孟造影では34\%に space occupying lesion がみられたといら.

尿管腫瘍の特徽の 1 つとして，尿路の他の部位にも同 し移行上皮性腫瘍が発生することがあり，自験例では21 名中 7 名, $33 \%$ に腎盂, 膀胱または反対側尿管に腫湟の 発生をみている。このらち術後に膀羘腫場のみられたる のは 2 例, $10 \%$ で, 術後 4 力月, 11 力月目に発見されて いる. Williams ${ }^{1)}$ は尿管腫瘍34例中11例, $32 \%$ に術後膀 腅腫湟が 発見されたが，その期間は平均13カ月である といい, Bloom ${ }^{3)}$ は102例中 $20 \%$ は術後平均19カ月で尿 路上皮腫瘍が生じたという．また Batata ${ }^{2)}$ は41例中12 例， $29 \%$ に膀羘腫瘍の発生をみているが，その期間は 6 カ月〜 3 年, 平均 2 年であつたといら。したがつてわれ われは尿管腫瘍の手術後, 定期的な膀胱鏡検査を最初の 3 年間は 3 カ月毎に行ない, 次の 2 年間は 6 カ月毎に, その後は 1 年毎に行ならようにしている.

一方膀胼腫瘍の治療後に尿管腫瘍の発見されたのは 3 例で，その期間は 3 年 1 力月， 7 年 5 カ月， 8 年 2 力月 とかなりの間隔がみられた. Williams ${ }^{1}$ 。16例の観察か ら, 膀胱腫場の訅断から尿管腫瘍の発見までの平均期間 は 4 年10カ月であつたといつている.

尿管腫瘍の診断は比較的困難なことが多い，本症の早 期診断のためには，まず血尿がみられた時に腎，膀胀腫 瘍とともに尿管腫瘍を念頭に扣くことが大切である.さ らに1）尿管に充満欠損がある時，2）明らかな原因が ないのに水腎症がみられる時，3）無造影腎で, 特に尿 管に通過障害のある時は本症を疑わなければならない。
また自験例で，血尿を主訴として来院したが初診時題微 鏡的血尿もなく，排泄性腎孟造影で腎孟尿管像も全く正 常のため 3 カ月毎に follow up していたところ, 11カ月 後の排泄性腎孟造影で軽度水腎症が認められ，精査の結 果本症と診断し得た例があることから，4）正常な腎孟 尿管像であつても尿管口からの血尿がみられるか，ある いは下部尿路に出血の原因のない時る尿管腫場を考える 必要がある。

尿管腫揚の根治術としては，尿管口周囲の膀胱壁切除 を含めた腎尿管全摘出術が行なわれており，われわれる 22例中18例， $82 \%$ に施行した。

しかし最近は腫瘍が単発性で限局性に存在し, 悪性度 および浸潤度が低く，且つ腎機能の此較的よく保存され ている例には尿管部分切除術が行なわれ，十分な成績が 得られている(213)14) 15)。われわれはこのような症例 2 例 と残腎尿管に発生した 1 例の計 3 例に尿管部分切除術を 行なつている.しかし手術に際しては, 術中に組織検査 を行なつて浸潤の程度, 細胞の悪性度, さらに切除尿管 断端に腫煌の存在しないことを確認することが大切であ る.また自験例 22 例中 3 例に腫暘が多発していたことよ り考えて, 腫瘍が単発であるとの確診が必要であり, 同 時に術後は再発に対して十分に注意することが肝要であ る。

尿管腫瘍に対する放射線療法および化学療法は，一般 的には効果が期待できないといわれる. しかし尿管腫瘍 は病理学的にも，あるいは放射線感受性に関しても膀胱 腫瘍と同様であるから，腫瘍の漫潤度が高い例や，非根 治手術に括わつた症例に対しては術後放射線療法を行な ら価值があると考えられ，われわれも7例に施行してい る.

尿管腫場の予後は不良で, 5 年生存率は $35 \sim 41 \%$ 2) 3) 6) といわれる。また Hawtrey') は52例中15例が生存し(平 均7.8年生存),37例が死亡（平均 2.9 年生存）したと報告 している。自験例 21 名の 5 年生存率は $40 \%$ で, 腎孟移 行上皮癌の $60 \%$ ) より不良であつた。これは尿管壁が 薄いこと，尿管からのリンパのドレナージが豊富で局 所への漫潤や転移が比較的早期より生ずる ${ }^{17)}$ うに, 診 断が困難で治療時には進行した例が多いためであろう。

予後に関与する大きな因子としては，腫瘍の悪性度と 漫潤度があげられる。 Williams ${ }^{1)}$ は組織学的 grade と 浸潤度は予後之直接相関するといい, Hawtrey4) る組織 学的悪性度と筋層への漫潤の程度は, 生存期間とよく相 関するとのべている. Bloom ${ }^{3)}$ は low grade の 5 年生 
存率は56\%であるのに対し, high grade では16\%であ クまた stage 別の 5 年生存率でも， stage I は $60 \%$, stage II 拈よびIII $28 \%$ で, stage IVでは 5 年生存例は なかつたといつている. 自験例です high grade および high stage 例の転帰は不良であつた。

Williams ${ }^{1)}$ は腎が触知されたり，水腎症であつた例の 予後は不良であるが，これは腫瘍が悪性であるほど早く 尿管を閉塞して水腎症, 腎腫大を来すためといつている. Batata ${ }^{2)}$ も排泄性腎孟造影で無機能であつた14例中12例 は 3 年以内に死亡したが，この14例中11例は進行癌であ つたといい，自験例でも腎が無造影であつた 6 例中 5 例 は 5 年以内に死亡しており, 無造影腎となつた尿管腫場 の転帰は不良である.

\section{結 語}

慈恵医大附属病院で，1960年より1976年までの17年間 に経験した尿管腫瘍21名, 22例について, 臨床的観察を 行なつた.

1） 21 名の平均年齢は63歳で，男子は女子の4.3倍で あつた。 患側は左側に多くみられたが， 1 例は 4 年の間 隔を招いて両側に発生した。

2）発生部位は下部 $1 / 3$ の尿管に最も多く，55\%にみ られた.ついで上部 $1 / 3$, 中部 $1 / 3$ の順であつたが, 22 例 中 3 例は腫場が多発していた。

3）初発症状は肉眼的血尿が18例（82\%）と最も多 く,ついで疼痛の 4 例であつた.

4）臨床症状としては肉眼的血尿が18例（82\%）と最 も多く, 疼痛 9 例 (41\%), 腫瘤 3 例 (14\%) の順であ つた. 全身倦怠感などの尿路外症状は 6 例 $(27 \%)$ 飞認 められた。

5）臨床検查では貧血が 4 例（18\%）飞, 赤沈穴進は 3 例 $(14 \%)$ にみられ， $\alpha_{2}$-globulin は4 例 $(27 \%)$ に 上昇しており，尿路感染は 2 例飞認められた。

6）尿中細胞診は12例中 2 例 $(17 \%)$ に陽性であつ た.

7）膀胱鏡検查では22例中 9 例（41\%）に尿管口から の腫場の突出や，出血〜血尿がみられた，尿管カテーテ ル法を行なつた15例では，14例（93\%）にカテーテルの 通過障害や尿の変化が認められた。

8）腎尿管膀胱部単純撮影では軟部腫瘤が 2 例にみら れたが，結石の合併したものはなかつた．尿路造影でみ られた主要な所見は, 腫瘍による尿管の充満欠損や通過 障害, 腫場存在部より上部の尿管および腎盂の払張であ
ク，22例中16例 $(73 \%)$ 飞認められた。また 6 例は無造 影腎であつた。

9） 21 名中 7 名 (33\%) は腎孟，膀脂または反対側の 尿管にも腫瘍の発生をみた.

10）22例中18例（82\%）は尿管口周辺の膀胼壁切除を 含めた腎尿管全摘出術を行ない， 3 例に尿管部分切除術 を施行した。

11） 21 名の 5 年生存率は $40 \%$ であり, 組織学的 grade と stage は予後と密接な関係がみられた。また腎が無造 影となつた例の転帰は不良であつた。

\section{文献}

1) Williams, C.B. and Mitchell, J.P.: Brit. J. Urol., 45, 377, 1973.

2) Batata, M.A., Whitmore, W.F. Jr., Hilans, B.S., Tokita, N. and Grabstald, H.: Cancer, 35, 1626, 1975.

3) Bloom, N.A., Vidone, R.A. and Lytton, B.: J. Urol., 103, 590, 1970.

4) Hawtrey, C.E.: J. Urol., 105, 188, 1971.

5）吉田和弘, 横山良望, 富田 勝, 西浦 弘, 宮 内十三郎, 秋元成大, 近喰利光, 川井 博: 臨 泌, 26, 705, 1972.

6) Abeshouse, B.S.: Am. J. Surg., 91, 237, 1956.

7）菱沼秀雄, 增田富士男, 佐々木忠正, 荒井由 和, 小路 良, 陳 瑞昌, 町田豊平, 小坂井守 : 日泌尿会誌, 68,780, 1977.

8）和志田裕人，上田公介：泌尿紀要， 17， 755, 1971.

9) 南 武, 增田富士男, 佐々木忠正 : 日泌尿会 誌, 66, 474, 1975.

10）增田富士男, 佐々木忠正, 高橋宣久, 荒井由和, 南 武: 泌尿紀要, 21, 595, 1975.

11) Sarnacki, C.T., McCormack, L.J., Kiser, W.S., Hazard, J.B., McLaughlin, T.C. and Belovich, D.M.: J. Urol., 106, 761, 1971.

12) 德中荘平, 広田紀昭, 辻一郎：西日泌尿, 38 , 681, 1976.

13）平石政治, 堀内誠三，中川完二，三浦枡也，親 松常男, 福谷恵子, 土屋文雄: 臨泌, 26, 401, 1972.

14) Petkvic, S. and Mutavdžic, M.: Brit. J. Urol., 40, 412, 1968.

15) Broom, H.E. and Roumani, G.K.: J. Urol., 112, 184, 1974.

16) Kim, K.H., Leiter, E. and Brendler, H.: J. Urol., 107, 955, 1972.

17) Scott, W.W.: J. Urol., 50, 45, 1943. （1977年 5 月 10 日受付） 